\title{
Activation of human invariant natural killer T cells with a thioglycoside analogue of $\alpha$-galactosylceramide
}

\author{
Andrew E. Hogan ${ }^{a, b, 1}$, Vincent O'Reilly ${ }^{a}$, Margaret R. Dunne ${ }^{a, b, 2}$, \\ Ravindra T. Dere ${ }^{c, 3}$, Shijuan G. Zeng ${ }^{a}$, Cashel O'Brien ${ }^{a}$, Sylvie Amu ${ }^{a}$, \\ Padraic G. Fallon ${ }^{a}$, Mark A. Exley ${ }^{\mathrm{d}}$, Cliona O'Farrelly ${ }^{\mathrm{e}}$, \\ Xiangming Zhu ${ }^{c}$, Derek G. Doherty ${ }^{a, b, *}$
}

\author{
a Institute of Molecular Medicine, Trinity College Dublin, St James's Hospital, Dublin, Ireland \\ b Institute of Immunology, National University of Ireland, Maynooth, Co. Kildare, Ireland \\ c Centre for Synthesis and Chemical Biology, University College Dublin, Co. Kildare, Ireland \\ d Cancer Biology Program, Hematology and Oncology Division, Beth Israel Deaconess Medical Center and Harvard Medical School, \\ Boston, USA \\ e School of Biochemistry and Immunology, Trinity College Dublin, Co. Kildare, Ireland
}

Received 22 September 2010; accepted with revision 17 March 2011 Available online 13 April 2011

\section{KEYWORDS \\ NKT cells; \\ Dendritic cells; \\ Human; \\ Cytokines; \\ Glycolipids}

\begin{abstract}
Activation of CD1d-restricted invariant NKT (iNKT) cells with the glycolipid $\alpha$-galactosylceramide ( $\alpha$-GalCer) confers protection against disease in murine models, however, clinical trials in humans have had limited impact. We synthesized a novel thioglycoside analogue of $\alpha$-GalCer, denoted $\alpha$-S-GalCer, and tested its efficacy for stimulating human iNKT cells in vitro. $\alpha$-SGalCer stimulated cytokine release by iNKT cells in a CD1d-dependent manner and primed CD1 $\mathrm{d}^{+}$ target cells for lysis. $\alpha$-S-GalCer-stimulated iNKT cells induced maturation of monocyte-derived dendritic cells into antigen-presenting cells that released IL-12 and small amounts of IL-10. The nature and potency of $\alpha$-S-GalCer and $\alpha$-GalCer in human iNKT cell activation were similar. However, in contrast to $\alpha$-GalCer, $\alpha$-S-GalCer did not activate murine iNKT cells in vivo. Because of its enhanced stability in biological systems, $\alpha$-S-GalCer may be superior to $\alpha$-GalCer as a parent compound for developing adjuvant therapies for humans.
\end{abstract}

(c) 2011 Elsevier Inc. All rights reserved.

Abbreviations: 7-AAD, 7-aminoactinomycin D; APC, antigen-presenting cell; CFSE, carboxyfluorescein succinimidyl ester; DC, dendritic cell; ELISA, enzyme-linked immunosorbent assay; FCS, foetal calf serum; $\alpha$-GalCer, $\alpha$ lpha-galactosylceramide, $\alpha$-S-GalCer, thioglycoside analogue of $\alpha$-GalCer; GM-CSF, granulocyte-monocyte colony-stimulating factor; IFN- $\gamma$, interferon- $\gamma$; IL, interleukin; iNKT cell, invariant natural killer T cell; LPS, lipopolysaccharide; mAb, monoclonal antibody; mfi, mean fluorescence intensity; MHC, major histocompatibility complex; PBMC, peripheral blood mononuclear cells; PE, phycoerythrin; PHA, phytohaemagglutinin; poly I:C, polyinosinic:polycytidylic acid; Th, helper T.

* Corresponding author at: Department of Immunology, Trinity College Dublin, Institute of Molecular Medicine, St. James' Hospital, Dublin 8, Ireland. Fax: + 35318963503 .

E-mail address: Derek.doherty@tcd.ie (D.G. Doherty).

1 AEH is currently in the Obesity Research Group, St. Vincent's University Hospital, University College Dublin, Ireland.

${ }^{2}$ MRD is currently at the National Children's Research Centre, Our Lady's Hospital for Sick Children, Crumlin, Dublin, Ireland.

${ }^{3}$ RTD is currently at Universität Konstanz, Fachbereich Chemie, Fach 725, 78457 Konstanz, Germany. 


\section{Introduction}

Invariant natural killer T (iNKT) cells are unconventional regulatory and effector $T$ cells that recognize glycolipid antigens presented by the major histocompatibility complex (MHC) class I-like molecule CD1d [1,2]. They can be activated by a number of endogenous and bacterial glycosphingolipids $[3,4]$, but the xenogeneic glycolipid, $\alpha$-galactosylceramide $(\alpha$-GalCer), a potent agonist for murine and human iNKT cells [5] has been used as the prototype antigen for most studies on iNKT cells. Upon in vitro activation with $\alpha$-GalCer, iNKT cells kill a range of tumor cell lines [6], rapidly release cytokines $[2,7,8]$, promote maturation of dendritic cells (DC) into antigen-presenting cells (APC) [9-12] and promote maturation of $B$ cells into antibody-secreting plasma cells $[13,14]$. Studies in murine models of disease have demonstrated critical roles for iNKT cells in the prevention and reversal of tumor growth, prevention of autoimmune disease, and immunity against a diversity of microbial pathogens [15-18]. Numerical and functional deficiencies of iNKT cells have been reported in humans with various diseases $[19,20]$ but clinical trials involving $\alpha$-GalCer stimulation of iNKT cells have yielded disappointing results [21,22].

A notable feature of iNKT cells is their ability to rapidly release cytokines that exert major effects on early and delayed adaptive immunity against tumors and infectious pathogens $[2,7,8] . \alpha$-GalCer stimulation of murine and human iNKT cells results in the simultaneous production of the Th1 cytokine interferon- $\gamma$ (IFN- $\gamma$ ) and the Th2 cytokines IL-4 and IL-13 $[7,8]$. Th1 cytokines are thought to be critical for the antitumor effects of $\alpha$-GalCer, while the Th2 cytokines can attenuate antitumor immunity and autoimmune disease pathology $[17,23,24]$. Therefore, the efficacy of $\alpha$-GalCer may be limited by reciprocal inhibition exhibited by Th1 and Th2 cytokines and this may be reflected in the low efficacy of $\alpha$-GalCer for the treatment of solid tumors in a phase I study [25]. Hence, a number of $\alpha$-GalCer derivatives and analogues have been synthesized to develop compounds which can selectively induce particular responses in iNKT cells. Modifications to the galactose residue revealed that the $\alpha$-anomeric configuration is a key pharmacophoric element of $\alpha$-GalCer $[26,27]$. Modifications to the acyl chains, including shortening [28-30] and the introduction of double bonds [31] resulted in iNKT cell ligands that preferentially stimulated Th2 cytokine secretion, while the addition of aromatic groups resulted in Th1-inducing ligands $[32,33]$. Substitution of the 0 -glycosidic linkage in $\alpha$-GalCer with a C-glycosidic linkage resulted in a Th1-inducing compound with 100 -fold greater antimetastatic activity in mice [34]. Silk and co-workers [35] identified threitol ceramide as a weak iNKT cell agonist, which led to the advantage for some applications of less consequent killing of CD1d ${ }^{+}$APC by iNKT cells and lowered anergic effects on repeated exposure.

We recently synthesized a thioglycoside analogue of $\alpha$-GalCer ( $\alpha$-S-GalCer; Fig. 1) using a novel approach that resulted in the galactosyl thiol being produced exclusively as $\alpha$-anomers [36]. Here we show that this $\alpha$-S-GalCer compound binds CD1d and stimulates cytotoxicity and cytokine secretion by human peripheral blood iNKT cell lines and renders them capable of inducing maturation of DCs into

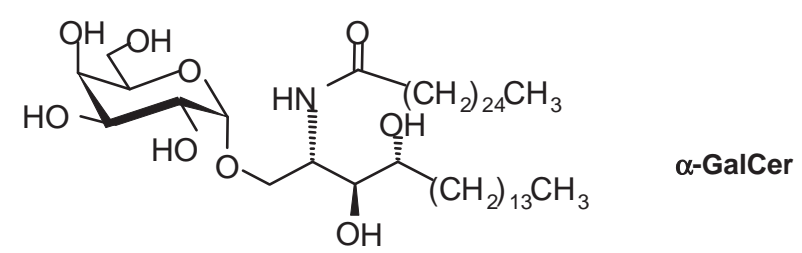

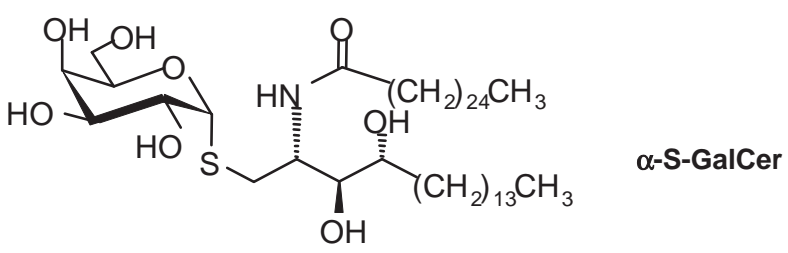

Figure 1 Molecular structures of $\alpha$-GalCer and the thioglycoside analogue ( $\alpha$-S-GalCer) used in the present investigation.

APCs. This is the first demonstration of a thioglycoside analogue of $\alpha$-GalCer that activates iNKT cells. Its increased stability in biological systems and enhanced flexibility around the anomeric linkage places $\alpha$-S-GalCer and its substituted derivatives as a potentially superior family of ligands, compared to $\alpha$-GalCer, for therapeutic activation of human iNKT cells.

\section{Materials and methods}

\subsection{Antibodies and flow cytometry}

Fluorochrome-conjugated monoclonal antibodies (mAb) specific for human CCR7, CD1d, CD3, CD4, CD8, CD11c, CD14, CD40, CD54, CD80, CD83, CD86, CD107a, HLA-DR, the V $\alpha 24$ and $V_{\beta} 11$ chains that form the T cell receptor (TCR) present on iNKT cells, the complementarity-determining region- 3 of the invariant $V_{\alpha} 24 J_{\alpha} 18$ TCR chain (6B11) and isotype control mAbs were obtained from BD Biosciences (Oxford, UK), Immunotools (Friesoythe, Germany), R\&D Systems (Abingdon, UK), eBioscience (Hatfield, UK) or Coulter Immunotech (Galway, Ireland). Following staining, cells were analyzed using a FACSCalibur flow cytometer with CellQuest software (BD Biosciences).

\subsection{Generation of iNKT cell lines}

Peripheral blood mononuclear cells (PBMC) were prepared from healthy blood donors by standard density gradient centrifugation over Lymphoprep (Nycomed Pharma, Oslo, Norway). iNKT cells were sorted from PBMC by staining with a phycoerythrin (PE)-conjugated anti-iNKT cell mAb (clone 6B11) followed by positive selection of the PE-positive cells by magnetic bead separation using anti-PE magnetic beads (Miltenyi Biotec, Bergisch-Gladbach, Germany). In some cases iNKT cells were enriched by flow cytometric sorting of 6B11-positive cells using a MoFlo ${ }^{\text {TM }}$ XDP Cell Sorter (Beckman Coulter).

Sorted iNKT cells were expanded in vitro using two different methods that were developed in our laboratory and yielded sufficient numbers of iNKT cells for functional studies. Method 1 involved culturing 1,000 iNKT cells in complete RPMI medium (RPMI 1640 containing $0.05 \mathrm{mM}$ 
L-glutamine, $0.05 \mathrm{mM} \beta$-mercaptoethanol, 10\% HyClone fetal calf serum or FCS, $1 \%$ penicillin-streptomycin, $1 \%$ fungizone and $25 \mathrm{mM}$ HEPES; Gibco-BRL, Paisley, UK and ThermoScientific, Logan, UT) and stimulating them with $1 \mu \mathrm{g} / \mathrm{ml}$ phytohaemagglutinin (PHA-P; Sigma-Aldrich, Dublin, Ireland) and $250 \mathrm{U} / \mathrm{ml} \mathrm{IL-2} \mathrm{(R \& D} \mathrm{Systems,} \mathrm{Abingdon,} \mathrm{UK)} \mathrm{in} \mathrm{the}$ presence of an excess $\left(2 \times 10^{5}\right)$ of irradiated allogeneic PBMC prepared from two donors. After $24 \mathrm{~h}$ and again after $48 \mathrm{~h}$, medium was replaced with medium containing $250 \mathrm{U} / \mathrm{ml} \mathrm{IL-2}$. Cells were restimulated as above every 28 days.

Method 2 for expanding iNKT cells involved culturing the cells in complete RPMI medium and giving them a single stimulation with $1 \mu \mathrm{g} / \mathrm{ml}$ plate-bound anti-CD3 mAb (OKT3 or HIT3A; BD Biosciences) in the absence of irradiated feeder cells. After $24 \mathrm{~h}$, the medium was supplemented with $100 \mathrm{U} / \mathrm{ml}$ of IL-2 and cells were cultured for 2 weeks, after which spent medium was replaced with complete RPMI containing $50 \mathrm{U} / \mathrm{ml}$ IL-2. Cells were split into multiple wells when confluency exceeded $50 \%$. Purity and phenotype of iNKT cell lines were assessed by flow cytometry after staining the cells with mAbs specific for CD3, 6B11, $\mathrm{V}_{\alpha 24,} \mathrm{~V}_{\beta} 11, \mathrm{CD} 4$ and CD8.

\subsection{Glycolipids}

$\alpha$-GalCer (KRN7000) was purchased from Funakoshi Co. Ltd, (Tokyo, Japan). The thioglycoside analogue of $\alpha$-GalCer ( $\alpha$-S-GalCer) was synthesized as described previously [36]. Briefly, $\alpha$-galactosyl thiol was prepared from the benzylated 1,6-anhydrogalactose in very high yield, and then coupled with the electrophilic sphingoid iodide under phase transfer conditions, to give the $\alpha$-linked product. Notably, the $\alpha$-galactosyl thiol was produced exclusively as $\alpha$-anomer, which made the purification simple and straightforward. Eventually the $\alpha$-S-GalCer was synthesized in a linear sequence of 14 steps with $3 \%$ overall yield.

Glycolipid stocks were prepared by suspending solid $\alpha$-GalCer or $\alpha$-S-GalCer in dimethylsulphoxide (DMSO) to a final concentrations of $1 \mathrm{mM}$ by heating for $2 \mathrm{~min}$ at $80^{\circ} \mathrm{C}$ followed by sonication for $5 \mathrm{~min}$ and vortexing for $1 \mathrm{~min}$. These stocks were stored at $-20{ }^{\circ} \mathrm{C}$. Working stocks containing $100 \mu \mathrm{M}$ glycolipids were made by further dilution in phosphate buffer saline by heating for $2 \mathrm{~min}$ at $80^{\circ} \mathrm{C}$ followed by sonication for $10 \mathrm{~min}$ and vortexing for $1 \mathrm{~min}$. These stocks were stored at $4{ }^{\circ} \mathrm{C}$ before adding to cell cultures.

\subsection{Analysis of cytokine secretion by iNKT cells}

iNKT cells were stimulated in vitro using mock-transfected or CD1d-transfected HeLa [33] or C1R cells [7] pulsed with glycolipid or vehicle. The HeLa and C1R transfectant cells were a kind gift from Steven Porcelli (Albert Einstein College of Medicine, New York, USA) and were maintained at a density of $0.5 \times 10^{6}$ cells $/ \mathrm{ml}$ in complete DMEM and RPMI medium, respectively, at $37{ }^{\circ} \mathrm{C}$ with $5 \% \mathrm{CO}_{2} .2 \times 10^{5} \mathrm{HeLa}$ or C1R mock- or CD1d-transfectant cells were cultured in round-bottomed 96-well tissue culture plates and pulsed with various amounts of glycolipid antigen or vehicle control for 2-24 h before adding an equal number of iNKT cells, which were expanded as described above but allowed to rest by culturing for 4 weeks in the absence of stimulation. After
24-72 h, supernatants were assayed for granulocyte-monocyte colony-stimulating factor (GM-CSF), IFN- $\gamma$, IL-4 or IL-13 by enzyme-linked immunosorbent assay (ELISA) using antibody pairs purchased from R\&D Systems. In some cases, blocking anti-CD1d (clone 42.1) mAb was added at a concentration of $10 \mu \mathrm{g} / \mathrm{ml}$ to test for CD1d dependency.

\subsection{Cytotoxicity assays}

The capacity of $\alpha$-GalCer and $\alpha$-S-GalCer to prime CD1 $d^{+}$C1R cells for cytotoxicity by iNKT cells was tested using the flow cytometry-based Total Cytotoxicity and Apoptosis Detection Kit (Immunochemistry Technologies, Bloomington, MN, USA). Briefly, target cells were incubated with a 1:250 dilution of stock carboxyfluorescein succinimidyl ester (CFSE) at $37{ }^{\circ} \mathrm{C}$ with $5 \% \mathrm{CO}_{2}$ for $30 \mathrm{~min}$. The reaction was quenched by adding $10 \mathrm{ml}$ cold cRPMI. Target cells were pelleted at low speed and incubated with expanded iNKT cells at ratios of 1:1, 10:1 and $20: 1$ for $4 \mathrm{~h}$ at $37{ }^{\circ} \mathrm{C}$ with $5 \% \mathrm{CO}_{2}$. After incubation, cells were harvested and incubated on ice. 7-aminoactinomycin D (7-AAD; 1:10 dilution) was added immediately before acquisition by flow cytometry. An electronic gate was used to select the CFSE positive target cells. CFSE positive cells which stained positive for 7-AAD are deemed to be recently apoptosed cells. Cytolytic degranulation of iNKT cells cultured with CD1d $\mathrm{d}^{-}$and CD1d ${ }^{+}$C1R cells, Jurkat and THP-1 target cells was examined by flow cytometric analysis of CD107a expression by 6B11-positive effector cells. In these experiments, iNKT cells and target cells were co-cultured for $4 \mathrm{~h}$ in the presence of anti-CD107a mAb and monensin ( $25 \mu \mathrm{M}$; Sigma-Aldrich) was added after $1 \mathrm{~h}$ to prevent reinternalisation of CD107a.

\subsection{DC functional assays}

Monocytes were enriched from PBMC isolated from buffy coat packs by positive selection using CD14 Microbeads (Miltenyi Biotec). CD14 ${ }^{+}$PBMC (containing $>90 \%$ CD14 ${ }^{+}$cells) were allowed to differentiate into immature $D C$ by culturing them at a density of $10^{6}$ cells $/ \mathrm{ml}$ using $3 \mathrm{ml} /$ well of a 6 -well plate (Corning, Amsterdam, Netherlands) in complete RPMI medium made with low-endotoxin FCS (Defined serum, HyClone) containing $50 \mathrm{ng} / \mathrm{ml}$ GM-CSF and $70 \mathrm{ng} / \mathrm{ml} \mathrm{IL-4}$. Cells were cultured for 6 days, replacing with fresh medium containing cytokines on day 3. Cells in some wells were cultured similarly but in the absence of cytokines, as monocyte controls. On day 6, DC were removed from the wells by aspiration using a wide-gauge Pasteur pipette whereas monocytes were gently scraped from the wells using a cell scraper (Sarstedt, Drinagh, Ireland). Cells were washed with warm RPMI medium. Flow cytometry was used to verify that differentiation into $D C$ had taken place and cells expressed HLA-DR and CD11c but not CD14.

DC were cultured at $0.2 \times 10^{6}$ cells/well in 96 -well plates and induced to mature by culturing them for $24 \mathrm{~h}$ in medium alone or with lipopolysaccharide (LPS; $1 \mu \mathrm{g} / \mathrm{ml}$; Alexis Biochemicals, Exeter, UK), polyinosinic:polycytidylic acid (poly l:C) double stranded RNA (75 $\mu \mathrm{g} / \mathrm{ml}$; Sigma-Aldrich), or equal numbers of allogeneic iNKT cells in the absence or presence of $\alpha$-GalCer or $\alpha$-S-GalCer. In some wells PBMC expanded using Methods 1 or 2, as described above for 
expanding iNKT cells, were included as a non-iNKT cell control. After $24 \mathrm{~h}$, the cell supernatants were assayed for IL10 and IL-12p70 production by ELISA (R\&D Systems) and DC were examined for expression of CCR7, CD11C, CD40, CD54, CD80, CD83, CD86 and HLA-DR using flow cytometry.

\subsection{In vivo studies in mice}

Female C57BL/6J mice (Harlan, UK) were injected intravenously with 1 or $2 \mu \mathrm{g} \alpha$-GalCer or $\alpha$-S-GalCer prepared in PBS. PBS-alone was also injected as a vehicle control. Blood was removed and serum recovered 3 and $18 \mathrm{~h}$ after injection. The levels of IFN- $\gamma$ and IL-4 in serum were determined by ELISA using reagents purchased from R\&D Systems (Minneapolis, MN, USA).

\subsection{Statistical analyses}

Statistical analysis was carried out using Prism GraphPad Version 5.0. Differences between groups were assessed using the Mann-Whitney $U$ test or paired $t$ test where appropriate. $p$ Values of $<0.05$ were considered significant.

\section{Results}

\subsection{Generation of iNKT cell lines}

iNKT cell lines were generated using Method 1 (PHA, irradiated feeders and IL-2) or Method 2 (anti-CD3 mAb and IL-2) and phenotypically examined by flow cytometry. iNKT cell lines prepared using both methods yielded similar numbers of cells and consisted of $\mathrm{CD}^{+}, \mathrm{CD}^{+}$and CD4 ${ }^{-} \mathrm{CD} 8^{-}$ double negative iNKT cells (Fig. 2), indicating that all three subsets could be expanded.

\subsection{Human iNKT cells release Th1 and Th2 cytokines in response to $\alpha-S-G a l C e r$ presented by CD1d}

iNKT cells expanded using Method 1 (PHA, irradiated feeder cells and IL-2) were co-cultured with equal numbers of mocktransfected or CD1d transfected HeLa cells that were unloaded or loaded with varying concentrations of $\alpha$-GalCer or $\alpha$-S-GalCer. After $24 \mathrm{~h}$, supernatants were harvested and assayed for levels of cytokines secreted by ELISA. Results from 5 experiments using three different iNKT cell lines showed that iNKT cells responded to both glycolipids in the presence of CD1d-transfected HeLa cells but not in the presence of mock-transfected HeLa cells (Fig. 3A). Both $\alpha$-GalCer and $\alpha$-S-GalCer induced the secretion of GM-CSF, IFN- $\gamma, \mathrm{IL}-4$ and IL-13 by iNKT cells in a dose-dependent manner. The levels of each cytokine released in response to the two glycolipids did not differ significantly, suggesting that substituting the 0 -glycosidic linkage on $\alpha$-GalCer with an S-linkage does not skew the Th1/Th2 cytokine balance of iNKT cells. Similar results were obtained using iNKT cells expanded using Method 2 (anti-CD3 mAb and IL-2) co-cultured with mock-transfected and CD1d-transfected C1R cells (Fig. 3B). Data from 6 experiments using six different iNKT cell lines show that both $\alpha$-GalCer and $\alpha$-S-GalCer stimulated IFN- $\gamma$ and IL-4 production by iNKT cells and this was blocked by preincubating the $C D 1 d^{+}$C1R cells with an anti-CD1d mAb. Thus, $\alpha$-S-GalCer stimulates human iNKT cells in a CD1ddependent manner inducing similar patterns of cytokine secretion as the prototype glycolipid $\alpha$-GalCer.

\section{3. $\alpha$-S-GalCer primes CD1d-positive target cells for lysis by iNKT cells}

Expanded iNKT cells were co-cultured with mock-transfected or CD1d-transfected C1R cells or the CD1d-positive transformed cells lines Jurkat and THP-1 in the absence or presence of $100 \mathrm{ng} / \mathrm{ml} \alpha$-GalCer or $\alpha$-S-GalCer. After $4 \mathrm{~h}$, cytolytic degranulation of the iNKT cell effector cells was measured by flow cytometric analysis of cell-surface CD107a expression (Fig. 4A). Figure 4A and $B$ shows that little or no degranulation occurred in the absence of CD1d expression by the target cells or addition of glycolipids. Both glycolipids significantly primed $\mathrm{CD} 1 \mathrm{~d}^{+}$target cells for degranulation by iNKT cells with $\alpha$-S-GalCer being significantly less potent than the parent $\alpha$-GalCer. Apoptosis of CFSE-labelled target cells was also examined by culturing mock- or CD1dtransfected C1R cells with iNKT cells at various effector/ target ratios in the absence or presence of $100 \mathrm{ng} / \mathrm{ml} \alpha$ GalCer or $\alpha$-S-GalCer. After $4 \mathrm{~h}$, apoptotic CFSE-positive cells were detected by flow cytometric analysis of 7-AAD expression (Fig. 4C). Figure 4D shows that iNKT cells in the absence of added antigen displayed weak cytotoxicity against $C D 1 d^{+}$C1R target cells. Addition of either glycolipid resulted in increased cytolytic activity. No cytotoxicity was observed when mock-transfected C1R cells were used as
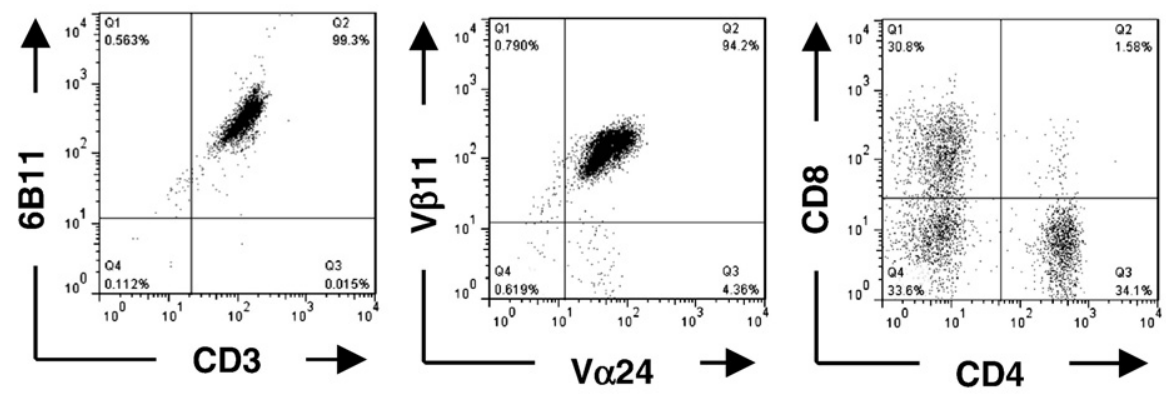

Figure 2 Purity and phenotype of iNKT cell lines. iNKT cells were sorted from human blood and expanded as described in Materials and methods. Flow cytometry dot plots show expression of CD3 and the iNKT TCR (6B11) (left), V $\alpha 24$ and V $\beta 11$ TCR chains (centre) and CD4 and CD8 (right) by a representative iNKT cell line. 
A
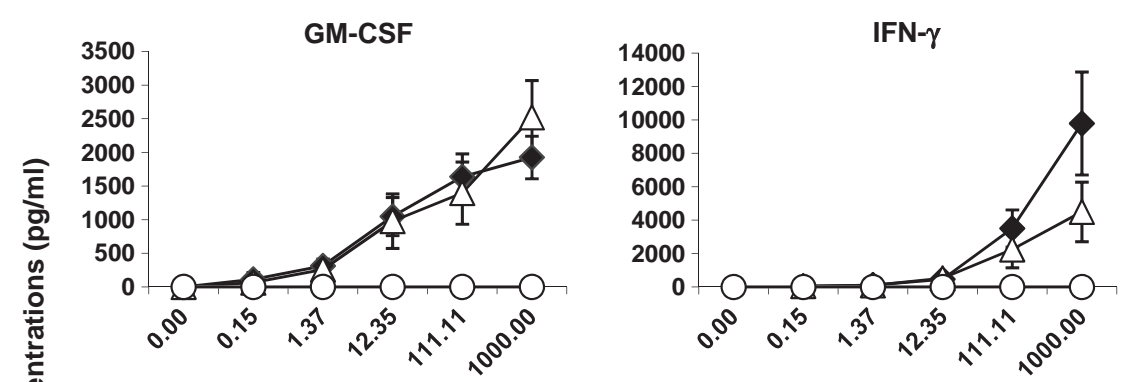

IL-4
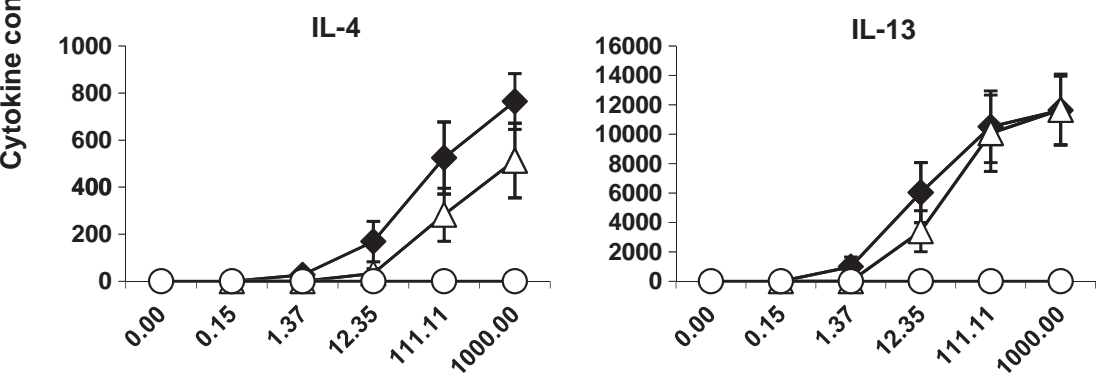

Glycolipid concentration (ng/ml)

\begin{tabular}{|c|c|}
\hline & HeLa-CD1d/ $\alpha-G a I C e r$ \\
\hline & HeLa-CD1d/ $\alpha-S-G a I C e r$ \\
\hline-0 & HeLa-mock/ $\alpha$-GalCer or $\alpha-S-G a I C e r$ \\
\hline
\end{tabular}

B
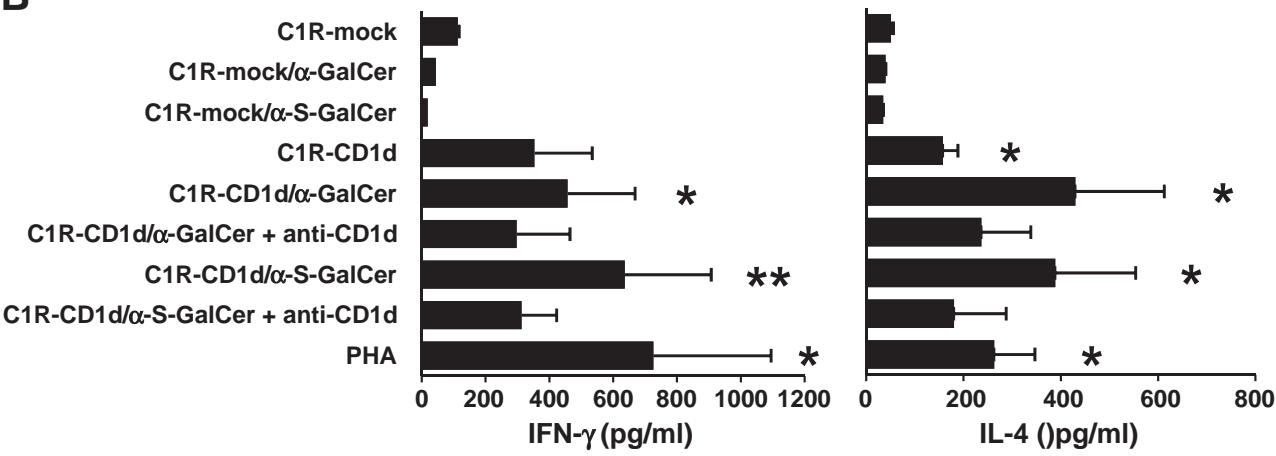

Figure 3 Human iNKT cell recognize $\alpha$-S-GalCer in a CD1d-dependent manner. A, iNKT cells were co-cultured with mocktransfected or CD1d transfected HeLa cells unloaded or loaded with varying concentrations of either $\alpha$-GalCer or $\alpha$-S-GalCer and levels of released GM-CSF, IFN- $\gamma$, IL- 4 and IL-13 were examined $48 \mathrm{~h}$ later by ELISA. Results show mean and SD cytokine levels from 5 independent experiments using 3 different iNKT cell lines (one experiment using the mock-transfectant cell line). B, iNKT cells were co-cultured with mock-transfected or CD1d-transfected C1R cells in the absence or presence of $100 \mathrm{ng} / \mathrm{ml} \alpha-\mathrm{GalCer}$ or $\alpha$-S-GalCer, with each treatment in the absence or presence of a blocking anti-CD1d mAb. Levels of released IFN- $\gamma$ (left) were measured after $72 \mathrm{~h}$ by ELISA. Levels of IL-4 (right) were measured after $24 \mathrm{~h}$. The bar graphs display the mean levels of cytokine secretion from 6 independent experiments. ${ }^{*} p<0.01 ;{ }^{* *} p<001$ compared to cytokine levels released by C1R-mock cells alone.

targets in the absence or presence of either glycolipid (data not shown). Thus, $\alpha-S-G a l C e r$ induces cytotoxicity by iNKT cells against some tumor cells but with a stimulatory capacity that may be less potent than $\alpha$-GalCer.

\section{4. $\alpha$-S-GalCer-stimulated iNKT cells induce maturation of monocyte-derived DC}

iNKT cells can induce maturation of immature DC into APCs that are capable of activating naïve $\alpha \beta$ T cells [9-12]. We compared the capacity of $\alpha$-S-GalCer and $\alpha$-GalCer in combination with iNKT cells to induce DC expression of MHC, costimulatory and adhesion molecules that are associated with antigen presentation. The intensities of $\mathrm{mAb}$ staining for each marker were determined by flow cytometry (Fig. 5A) and the fold-increases in the average mean MFI of marker expression over those of immature DC were determined for 3 independent experiments. Immature monocyte-derived DC incubated for $24 \mathrm{~h}$ with LPS or poly I:C exhibited significant upregulation of CCR3, CD40, CD54, CD86 and HLA-DR but not CD83 nor CD80 (Fig. 5B). Incubation 
A
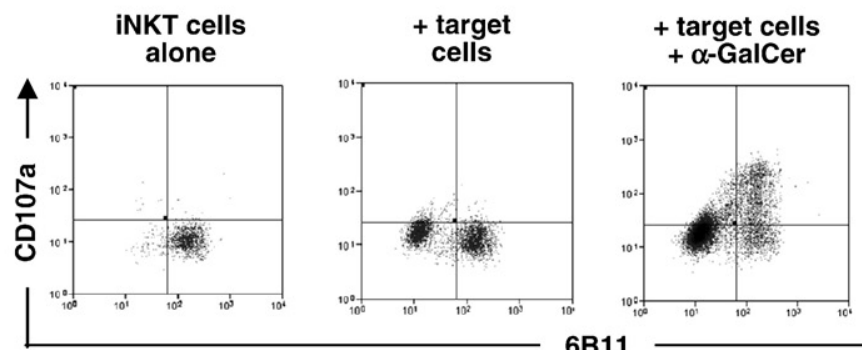

+ target cells $+\alpha$-S-GalCer

6B11
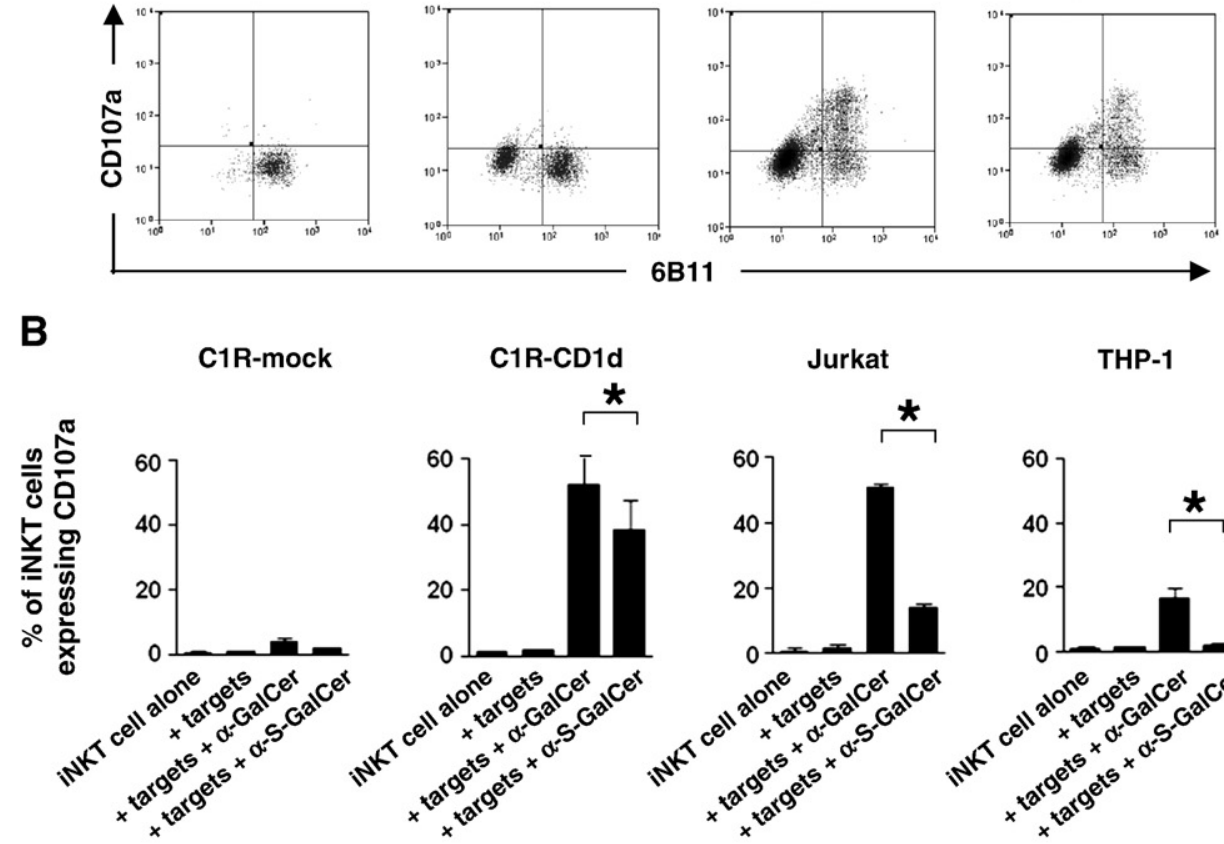

C

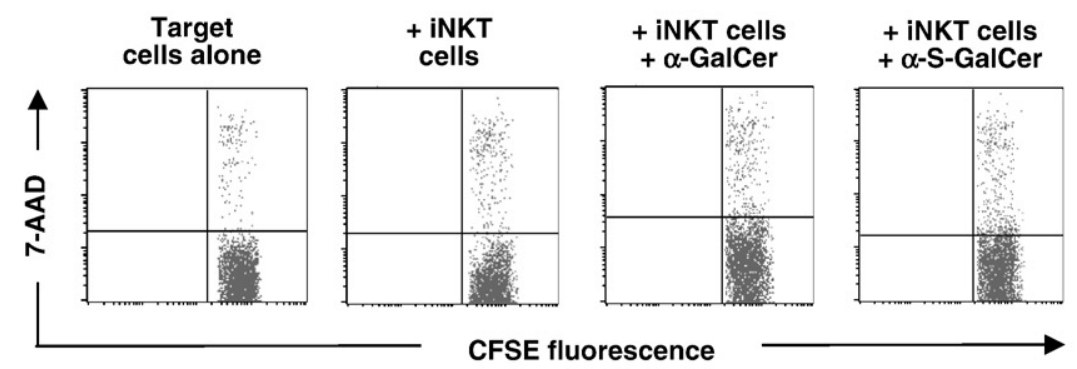

D

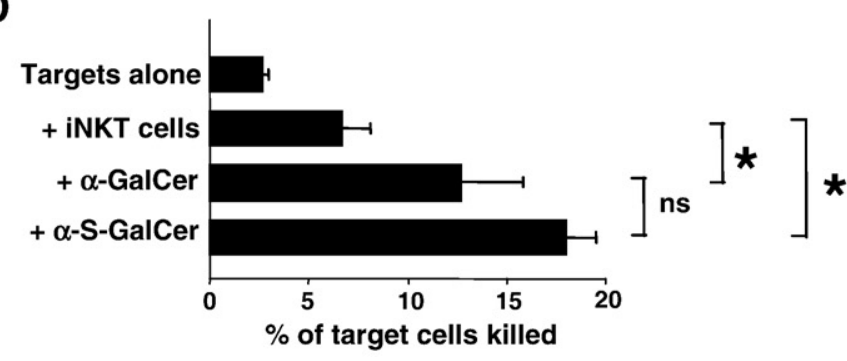

Figure $4 \alpha$-S-GalCer primes CD1d-positive target cells for lysis by iNKT cells. A, Flow cytometric dot plots showing cell surface expression of CD107a by iNKT cells $\left(6 \mathrm{~B} 11^{+}\right)$incubated alone or following culture for $4 \mathrm{~h}$ with CD1d-transfected C1R target cells unloaded or loaded with $100 \mathrm{ng} / \mathrm{ml} \alpha$-GalCer or $\alpha$-S-GalCer. B, Percentages of iNKT cells that expressed CD107a after culture with mock- or CD1d-transfected C1R cells, Jurkat or THP-1 cells in the absence or presence of $\alpha$-GalCer or $\alpha$-S-GalCer. Results are means $( \pm$ SEM of experiments using 3 different iNKT cell lines. C, Flow cytometric dot plots showing expression of 7-aminoactinomycin D (7-AAD) by CFSE-labeled CD1d-transfected C1R cells cultured alone or in the presence of iNKT cells at effector/target ratios of 10/ 1 in the presence of $100 \mathrm{ng} / \mathrm{ml} \alpha$-GalCer or $\alpha$-S-GalCer. D, Mean percentages of CFSE labeled CD1d transfected C1R target cells that expressed 7-AAD after culturing with iNKT cells in the absence or presence of $\alpha$-GalCer or $\alpha-\mathrm{S}$-GalCer. Results are means of 3 independent experiments with different iNKT cell lines. ${ }^{*} p<0.005$.

of DCs with equal numbers of iNKT cells in the absence of glycolipid antigen also resulted in significant upregulation of CD54 and CD86 expression and weak (non-significant) upregulation of expression of the other markers that were induced by LPS or poly I:C. Addition of $\alpha$-GalCer or $\alpha$-S-
GalCer to the DC-iNKT cell co-cultures resulted in further upregulation of CCR7, CD40, CD54, CD83, CD86 and HLA-DR with both glycolipids having similar effects. As controls, noniNKT cells consisting of PBMC expanded using PHA and IL-2 were also co-cultured with the DC, but these cells did not 
A
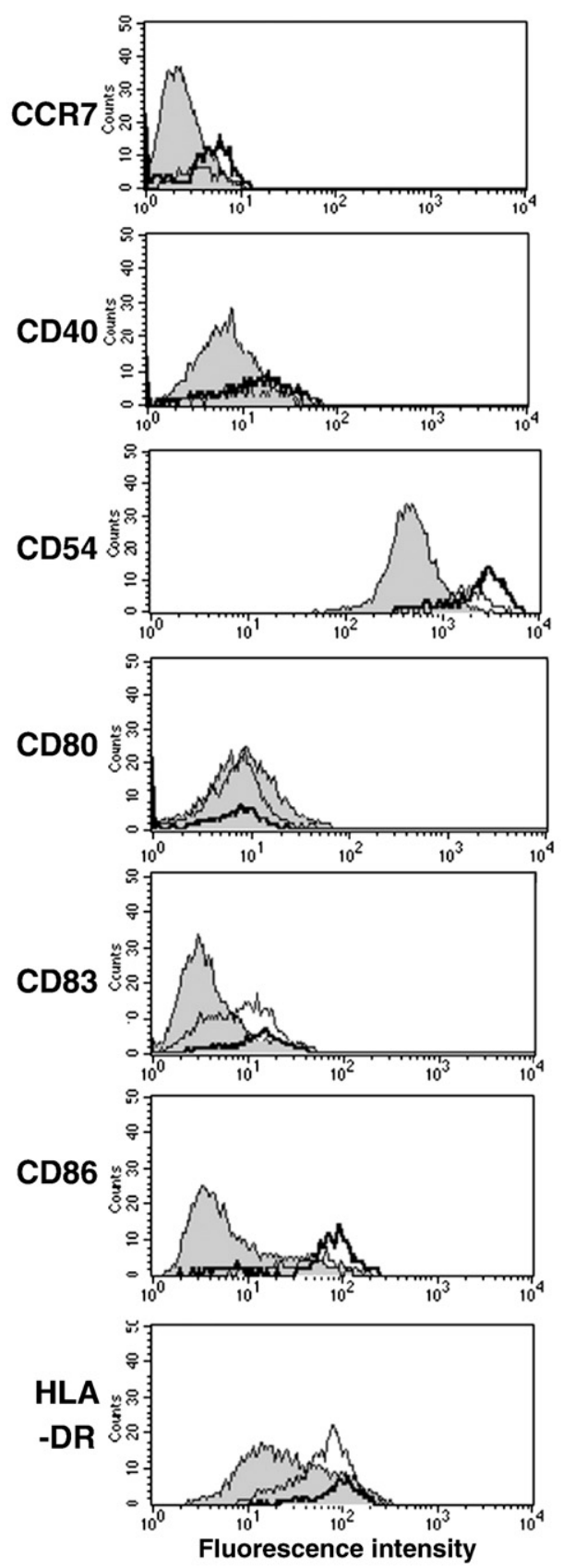

B
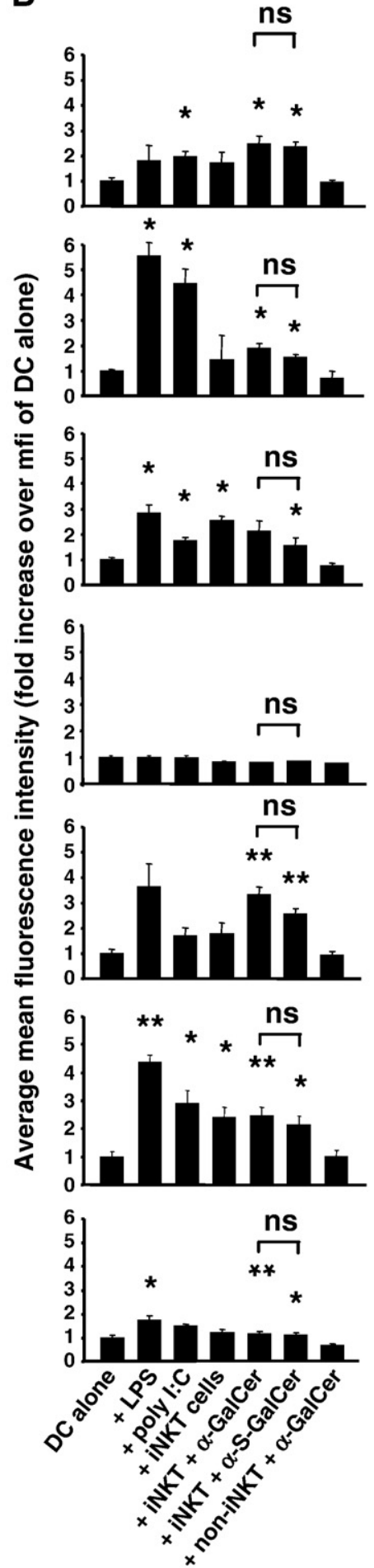

Figure $5 \alpha$-S-GalCer-stimulated iNKT cells induce maturation of monocyte-derived DC. Immature monocyte-derived DC were incubated for $24 \mathrm{~h}$ in medium alone or with $1 \mu \mathrm{g} / \mathrm{ml}$ LPS, $75 \mu \mathrm{g} / \mathrm{ml}$ poly I:C double stranded RNA or equal numbers of iNKT cells in the absence or presence of $\alpha$-GalCer and $\alpha$-S-GalCer. Non-iNKT cells consisted of PBMC expanded with PHA and IL-2 as a control cell population. A, Representative flow cytometry histograms showing intensities of CCR7, CD40, CD54, CD80, CD83, CD86 and HLA-DR expression by iDC cultured alone (filled histograms), cultured with iNKT in the presence of $\alpha$ GalCer (thin lines) or cultured with iNKT in the presence of $\alpha$-S-GalCer (bold lines). B, Bar charts showing the average mean fluorescence intensities (mfi) in 3 independent experiments expressed as fold increases in mfi compared with the mfi of immature DC. ${ }^{*} p<0.05$ and ${ }^{* *} p<0.01$ compared with the mfi of immature DC; ns, not significant comparing the effects of $\alpha$-GalCer and $\alpha$-S-GalCer (shown by square brackets). 
A
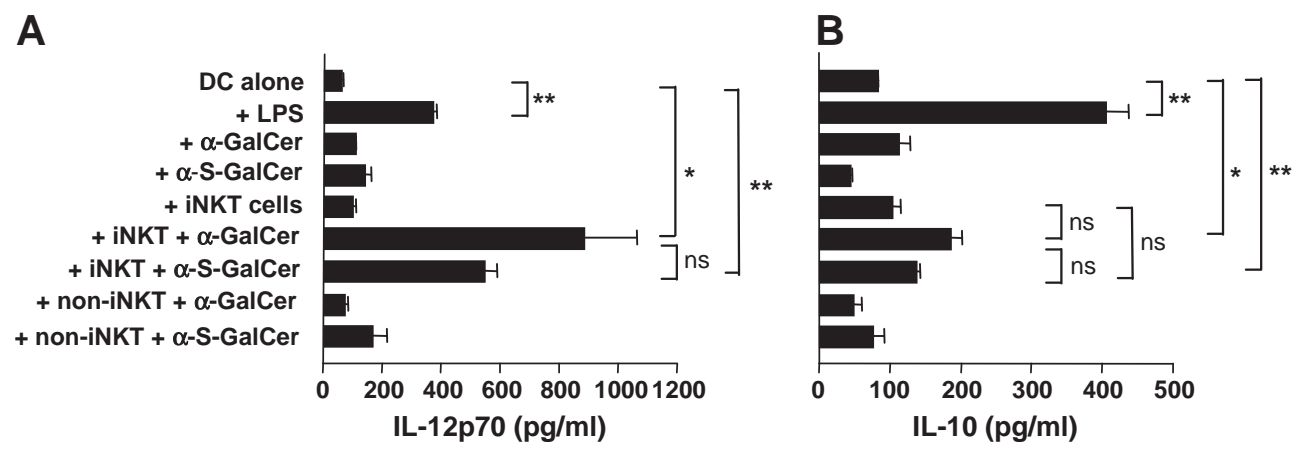

Figure $6 \alpha$-S-GalCer stimulated iNKT cells induce IL-12, and to a lesser degree, IL-10 release by monocyte-derived dendritic cells (DC). Immature DC were cultured in medium alone, with $1 \mu \mathrm{g} / \mathrm{ml}$ LPS, $100 \mathrm{ng} / \mathrm{ml} \alpha$-GalCer or $\alpha$-S-GalCer, or co-cultured with iNKT cells or non-iNKT cells in the absence or presence of $\alpha$-GalCer or $\alpha$-S-GalCer. The levels of IL-12 (A) and IL-10 (B) released into culture supernatants were measured after $24 \mathrm{~h}$ by ELISA. Results are the means and SEM of 3 separate experiments. Square brackets indicate which statistical comparisons are being made. ${ }^{*} p<0.05 ;{ }^{* *} p<0.01$; ns, not significant.

induce or upregulate marker expression by DC whether or not glycolipids were present. These results indicate that iNKT cells can partially induce DC maturation into cells with APC phenotypes and that this maturation is augmented by activating the iNKT cells with either $\alpha$-S-GalCer or $\alpha$-GalCer.

\section{5. $\alpha$-S-GalCer-stimulated iNKT cells induce IL-12, and to a lesser degree, IL-10 release by monocyte-derived DC}

We also measured the amounts of IL-12 and IL-10 released into supernatants by DC cultured alone or with LPS, $\alpha$-GalCer or $\alpha$-S-GalCer or by co-cultures of DC with iNKT cells in the absence or presence of $\alpha$-GalCer or $\alpha$-S-GalCer. Neither IL-12 nor IL-10 was released by DC cultured alone or with either glycolipid, but LPS treatment induced the rapid release of both IL-12 and IL-10 (Fig. 6). These cytokines were not released by co-cultures of DC and unstimulated iNKT cells. However, addition of $\alpha$-GalCer or $\alpha$-S-GalCer to DC-iNKT cell co-cultures resulted in secretion of IL-12, with higher levels that those induced by LPS. In contrast, co-cultures of DC and iNKT cells with $\alpha$-GalCer or $\alpha$-S-GalCer released small amounts of IL-10-significantly more than the amount released by immature $D C$, but only slightly more than DC matured with iNKT cells in the absence of glycolipid and less than that induced by LPS-matured DC (Fig. 6). No cytokines were released by DC co-cultured with PHA-stimulated PBMC, as a non-iNKT cell control, in the absence or presence of glycolipids. These data indicate that $\alpha$-GalCer and $\alpha$-SGalCer have similar immunostimulatory activities for DC, in that they confer iNKT cells with the capacity to induce potent IL-12 and moderate IL-10 secretion by DC.

\subsection{Intravenous administration of $\alpha$-GalCer, but not $\alpha-S-G a l C e r$, to mice resulted in elevated serum IFN- $\boldsymbol{\gamma}$ and IL-4}

Mice were injected intravenously with PBS-alone or PBS containing $1 \mu \mathrm{g}$ or $2 \mu \mathrm{g} \alpha$-GalCer or $\alpha$-S-GalCer and levels of IFN- $\gamma$ and IL- 4 in serum were measured after 3 and $18 \mathrm{~h}$ by ELISA. Figure 7 shows that $\alpha$-GalCer, at either dose, induced the secretion of significant amounts of both cytokines into serum by $3 \mathrm{~h}$ that was sustained to $18 \mathrm{~h}$. However, after injection with $\alpha$-S-GalCer, neither cytokine was detected at elevated levels compared to mice given PBS alone. These data suggest that, unlike $\alpha$-GalCer, the thioglycoside analogue does not activate murine iNKT cells in vivo.

\section{Discussion}

iNKT cells play central roles in innate and adaptive immunity, being capable of killing cells [6], inducing maturation of DC into antigen-presenting cells [9-12], promoting differentiation of $\mathrm{B}$ cells into antibody-secreting plasma cells $[13,14]$ and releasing large quantities of Th1, Th2, Th17 and regulatory $T$ cell cytokines $[7,8,37,38]$. This early immune stimulatory/regulatory role highlights the potential importance of iNKT cells in infectious, immunemediated and metastatic disease and therapeutic activation

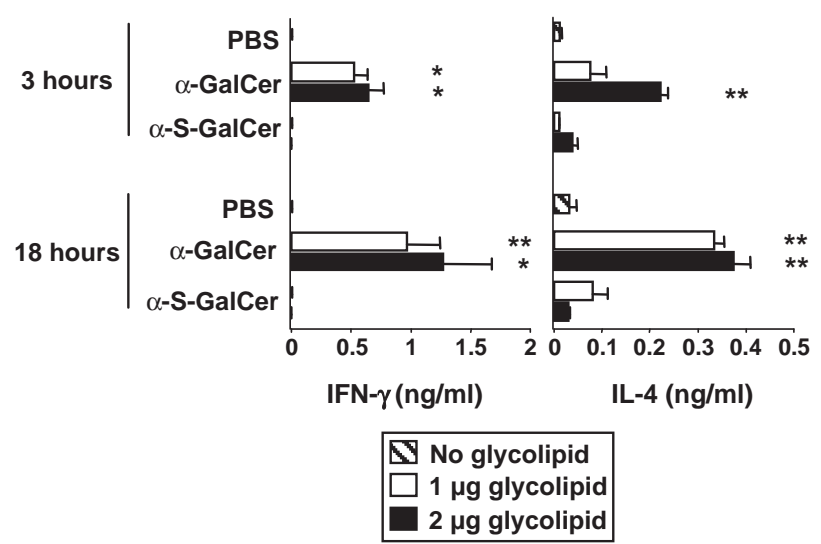

Figure 7 Intravenous administration of $\alpha$-GalCer, but not $\alpha$ S-GalCer, to mice results in elevated serum IFN- $\gamma$ and IL-4. Serum levels of IFN- $\gamma$ (left) and IL-4 (right) in mice after intravenous treatment with PBS alone or PBS containing $1 \mu \mathrm{g}$ or $2 \mu \mathrm{g} \alpha$-GalCer or $\alpha$-S-GalCer. Serum samples were harvested $3 \mathrm{~h}$ (top) or $18 \mathrm{~h}$ (bottom) after treatment. Data are from 3 to 6 mice per group and are representative of two separate experiments. ${ }^{*} p<0.05 ;{ }^{* *} p<0.01$ comparing effect of glycolipid with PBS controls. 
of iNKT cells can prevent and/or reverse a variety of diseases in murine models [15-18]. Although deficiencies of iNKT cells are found in humans with various diseases $[19,20]$, clinical trials for cancer involving $\alpha$-GalCer stimulation of iNKT cells have not yet demonstrated strong clinical efficacy $[21,22]$. One reason for this lack of clinical efficacy may be that iNKT cells are found at $\sim 100$-fold lower frequencies in humans compared to mice at most body locations tested [19,39]. Another may be that like in mice there are different NKT cell subsets with different activities [17,23,24] and it is possible that the "wrong" subsets were being used. A third possibility is that murine and human iNKT cell subsets may respond differently to $\alpha$-GalCer and given the pleiotropy of iNKT cell functions, it is likely that alternative glycolipid ligands may alter iNKT cell responses and may therefore have superior therapeutic value. In this regard, $\mathrm{OCH}$, a synthetic analogue of $\alpha$-GalCer with a truncated acyl chain and a truncated sphingoid base induces a predominant Th2 response in iNKT cells and confers superior protection against experimental autoimmune encephalomyelitis [28], collagen-induced arthritis [40], diabetes [41]) and colitis [42]) in murine models. Another $\alpha$-GalCer analogue, $\alpha$-GalCer C20:2, with a truncated, unsaturated acyl chain was found to have an even stronger protective effect against murine diabetes than $\mathrm{OCH}$ [43]. In contrast, synthetic $\alpha$-GalCer analogues containing aromatic rings in their acyl or sphingosine tails, induced polarized Th1 responses in iNKT cells and thereby conferred superior protection against breast and lung cancers [33,44]. A C-glycoside analogue of $\alpha$-GalCer ( $\alpha$-C-GalCer) also induced enhanced Th1 responses through iNKT cells and displayed 1000-fold more potent antimalarial activity and 100 -fold greater antimetastatic activity [34].

In this report, we show that a thioglycoside analogue of $\alpha$-GalCer has stimulatory activity for human iNKT cells. Thioglycosides, in which the glycosidic oxygen atom is replaced with a sulphur atom, are tolerated by most biological systems and are more resistant to enzymatic cleavage and chemical degradation $[45,46]$. Thioglycosides have more flexibility around the anomeric linkage compared with the corresponding O-glycosides owing to the longer C-S bond and weaker stereoelectronic effects. This increased flexibility might cause $\alpha$-S-GalCer to sit differently in the CD1d binding groove, resulting in an altered structure of the glycolipid/CD1d complex and a change in its avidity for the TCR of iNKT cells. Also, it is possible that after binding with CD1d, the sugar head of $\alpha-S-G a l C e r$ may orientate in a different angle from that of $\alpha$-GalCer as C-S-C bond angle is significantly smaller than the C-O-C angle, which could result in differential recognition by TCR of iNKT cells. We tested if $\alpha$-S-GalCer can bind to CD1d and activate iNKT cells and if it can induce altered responses of iNKT cells compared to $\alpha$-GalCer, which might translate into improved clinical responses.

Our results show that $\alpha$-S-GalCer stimulated human iNKT cells in a CD1d-dependent manner and induced similar patterns of cytokine secretion to those induced by the prototype glycolipid $\alpha$-GalCer. $\alpha$-S-GalCer also primed CD1dpositive target cells for lysis by iNKT cells. We also investigated if $\alpha$-S-GalCer could induce maturation of monocyte-derived DC into APC, a key event in the initiation of adaptive immune responses. We found that co-culturing immature DC with iNKT cells in the absence of glycolipid antigen resulted in upregulation of CD54 and CD86 expression by the DC. Addition of either $\alpha$-GalCer or $\alpha$-S-GalCer resulted in the additional upregulation of expression of CCR7, CD40, CD83 and HLA-DR to levels comparable to those induced by LPS and/or poly I:C. In contrast, iNKT cellmediated cytokine secretion by DC was dependent on the presence of glycolipid antigen. iNKT cells but not non-iNKT cells, in the presence of $\alpha$-GalCer or $\alpha$-S-GalCer induced the release of large amounts of IL-12 and moderate amounts of IL-10 by DC. Phenotypic maturation of DC in the absence of IL-12 production (as occurred when DC were co-cultured with iNKT cell alone) can lead to the development of tolerogenic DC [47] and it is tempting to speculate that addition of glycolipid to DC-iNKT cell co-cultures converts them from tolerogenic (CD86 $\left.{ }^{+} \mathrm{IL}-12^{-}\right)$to immunogenic (CD86 $\left.{ }^{+} \mathrm{IL}-12^{+}\right) \mathrm{DC}$.

While $\alpha$-S-GalCer displayed stimulatory activity for human iNKT cells in vitro, we were surprised to find that this glycolipid did not activate murine iNKT cells in vivo, as evidenced by the absence of elevated levels of serum IFN- $\gamma$ and IL-4. However, in the same mouse experiments and as previously reported [31,34], the prototype glycolipid $\alpha$-GalCer induced rapid secretion of both cytokines into serum. Blauvelt and co-workers [48] also reported no bioactivity of $\alpha-\mathrm{S}-\mathrm{GalCer}$ in mice. Our finding indicates that murine iNKT cells respond to $\alpha-\mathrm{S}-\mathrm{GalCer}$ in vivo differentially from human iNKT cells in vitro. Whether $\alpha$-S-GalCer stimulates murine iNKT cells in vitro and human iNKT cells in vivo remains to be tested. This difference between antigen recognition by murine and human iNKT cells highlights the importance of testing such therapeutic ligands with human cells.

Our results clearly show that $\alpha$-S-GalCer exhibits bioactivity by stimulating CD1d-dependent cytotoxic, cytokine and adjuvant activities of iNKT cells similar to those activated by $\alpha$-GalCer. Two other groups have synthesized similar $\alpha$-S-GalCer-type analogues but were unable to demonstrate recognition of this compound by iNKT cells. Chang and co-workers [33] synthesized and tested a number of $\alpha$-GalCer analogues and found that an $\alpha$-S-GalCer form presented by monocytes which were co-cultured with human iNKT cells failed to stimulate IFN- $\gamma$, IL-2, IL-6, IL10 or IL-12 release. This compound did induce weak IL-4 production but significantly lower amounts than those induced by $\alpha$-GalCer. Furthermore, $\alpha$-S-GalCer did not induce human iNKT cell proliferation, nor did it prolong survival of mice bearing lung or breast tumors, as occurred when $\alpha$-GalCer was used. In another study, Blauvelt and coworkers [48] administered an $\alpha$-S-GalCer to non-obese diabetic and C56B1/6 mice but, in accordance with our study, failed to demonstrate expansion of or intracellular cytokine expression by iNKT cells, or proliferation or cytokine production by splenocytes from these mice after restimulation with $\alpha$-S-GalCer. We are unable to say why our $\alpha$-S-GalCer showed bioactivity for human iNKT cells while bioactivity was not found in a previous study [33], but it may reflect the novel procedure used in our study for $\alpha$-S-GalCer synthesis. In our procedure, an $\alpha$-galactosyl thiol was prepared from a benzylated 1,6-anhydrogalactose and coupled it with an electrophilic sphingoid iodide under phase transfer conditions [36]. This method yielded S-GalCer exclusively as $\alpha$-anomers, whereas in the study by Blauvelt and co-workers [48], the construction of thioglycosidic bond 
was non-stereoselective, and $\alpha$-S-GalCer had to be isolated from the mixture of $\alpha$ - and $\beta$-galactosyl thiols after the coupling reaction. It is possible that low-levels of the $\beta$ enantiomer inhibited the effects of the $\alpha$-form.

In conclusion, we have shown that synthetic $\alpha$-S-GalCer can stimulate the effector, regulatory and adjuvant activities of human iNKT cells. It is not superior to its parent compound $\alpha$-GalCer in that it induces the release of the same cytokines with similar potency, it is a similar or less potent stimulator of antitumor cytotoxicity by iNKT cells, and it comparably induces maturation and cytokine secretion by dendritic cells in the presence of iNKT cells. Therefore, $\alpha-S-$ GalCer is unlikely to replace $\alpha$-GalCer as a therapeutic agent. However, $\alpha$-S-GalCer may be superior to $\alpha$-GalCer as a parent compound for developing therapeutic analogues with shorter acyl chains, more double bonds and/or added aromatic groups, as have been introduced to $\alpha$-GalCer and shown to alter iNKT cell stimulatory capacity [28-35] and therapeutic efficacy in mice [28,34,40-44]. Thioglycosides are easier to prepare than 0 -linked glycosides, since sulphur is much more nucleophilic than oxygen, allowing easier formation of the C-S bond. This has enabled several strategies for the synthesis of S-linked glycoconjugates to be developed $[36,46,49]$. Thioglycosides also display increased solubility and stability in biological systems [50-53]. S-linked glycoconjugates display lower susceptibility to chemical and enzymatic hydrolysis with the rate of hydrolysis of the thioglycosidic bond by glycohydrolases being several orders of magnitude lower that that of the corresponding 0linked glycosides [49]. Furthermore, glycoconjugates with at least one glycosidic oxygen atom replaced with a sulphur atom can act as competitive inhibitors of various glycoside hydrolases [54]. Our demonstration of the bioactivity of $\alpha$-SGalCer together its ease of synthesis, flexibility for making analogues and stability in biological systems, places thioglycoside analogues of $\alpha$-GalCer as potentially superior immune stimulants for human use.

\section{Conflict of interest statement}

The authors have no financial or commercial conflicts of interest to declare.

\section{Acknowledgments}

This work was supported by grants from Science Foundation Ireland (AEH, RTD and SA), the Irish Health Research Board (VO'R and SGZ) and the Irish Research Council for Science Engineering and Technology (MRD). MAE was supported by grants R01 DK066917 and R21 CA143748. We thank Steven Porcelli for providing the C1R and HeLa transfectant cell lines and Ann Atzberger for help with cell sorting. Thanks to Conleth Feighery, John Jackson, Jacinta Kelly, Melissa Conroy and Laura Madrigal-Estebas for helpful discussions.

\section{References}

[1] M. Brigl, M.B. Brenner, CD1: antigen presentation and T cell function, Annu. Rev. Immunol. 22 (2004) 817-890.
[2] A. Bendelac, P.B. Savage, L. Teyton, The biology of NKT cells, Annu. Rev. Immunol. 25 (2007) 297-336.

[3] D. Zhou, J. Mattner, C. Cantu III, N. Schrantz, N. Yin, Y. Gao, Y. Sagiv, K. Hudspeth, Y.P. Wu, T. Yamashita, S. Teneberg, D. Wang, R.L. Proia, S.B. Levery, P.B. Savage, L. Teyton, A. Bendelac, Lysosomal glycosphingolipid recognition by NKT cells, Science 306 (2004) 1786-1789.

[4] Y. Kinjo, D. Wu, G. Kim, G.W. Xing, M.A. Poles, D.D. Ho, M. Tsuji, K. Kawahara, C.H. Wong, M. Kronenberg, Recognition of bacterial glycosphingolipids by natural killer T cells, Nature 434 (2005) 520-525.

[5] T. Kawano, J. Cui, Y. Koezuka, I. Toura, Y. Kaneko, K. Motoki, H. Ueno, R. Nakagawa, H. Sato, E. Kondo, H. Koseki, M. Taniguchi, CD1d-restricted and TCR-mediated activation of $\mathrm{V}_{\alpha} 14$ NKT cells by glycosylceramides, Science 278 (1997) 1626-1629.

[6] L.S. Metelitsa, O.V. Naidenko, A. Kant, H.W. Wu, M.J. Loza, B. Perussia, M. Kronenberg, R.C. Seeger, Human NKT cells mediate antitumor cytotoxicity directly by recognizing target cell CD1d with bound ligand or indirectly by producing IL-2 to activate NK cells, J. Immunol. 167 (2001) 3114-3122.

[7] M. Exley, J. Garcia, S.P. Balk, S. Porcelli, Requirements for CD1d recognition by human invariant $\mathrm{V} \alpha 24^{+} \mathrm{CD} 4^{-} \mathrm{CD} 8^{-} \mathrm{T}$ cells, J. Exp. Med. 186 (1997) 109-120.

[8] J.E. Gumperz, S. Miyake, T. Yamamura, M.B. Brenner, Functionally distinct subsets of CD1d-restricted natural killer T cells revealed by CD1d tetramer staining, J. Exp. Med. 195 (2002) 625-636.

[9] H. Kitamura, K. Iwakabe, T. Yahata, S. Nishimura, A. Ohta, Y. Ohmi, M. Sato, K. Takeda, K. Okumura, L. Van Kaer, T. Kawano, M. Taniguchi, T. Nishimura, T, The natural killer T (NKT) cell ligand $\alpha$-galactosylceramide demonstrates its immunopotentiating effect by inducing interleukin (IL)-12 production by dendritic cells and IL-12 receptor expression on NKT cells, J. Exp. Med. 189 (1999) 1121-1128.

[10] M.S. Vincent, D.S. Leslie, J.E. Gumperz, X. Xiong, E.P. Grant, M.B. Brenner, CD1-dependent dendritic cell instruction, Nat. Immunol. 3 (2002) 1163-1168.

[11] S. Fujii, K. Shimizu, H. Hemmi, R.M. Steinman, Innate $\mathrm{V} \alpha 14^{+}$ natural killer T cells mature dendritic cells, leading to strong adaptive immunity, Immunol. Rev. 220 (220) (2007) 183-198.

[12] T.Y. Liu, Y. Uemura, M. Suzuki, Y. Narita, S. Hirata, H. Ohyama, O. Ishihara, S. Matsushita, Distinct subsets of human invariant NKT cells differentially regulate $T$ helper responses via dendritic cells, Eur. J. Immunol. 38 (2008) 1012-1023.

[13] G. Galli, S. Nuti, S. Tavarini, L. Galli-Stampino, C. De Lalla, G. Casorati, P. Dellabona, S. Abrignani, S, CD1d-restricted help to $B$ cells by human invariant natural killer T lymphocytes, J. Exp. Med. 197 (2003) 1051-1057.

[14] E.A. Leadbetter, M. Brigl, P. Illarionov, N. Cohen, M.C. Luteran, S. Pillai, G.S. Besra, M.B. Brenner, NK T cells provide lipid antigen-specific cognate help for B cells, Proc. Natl Acad. Sci. U.S.A. 105 (2008) 8339-8344.

[15] J. Cui, T. Shin, T. Kawano, H. Sato, E. Kond, I. Toura, Y. Kaneko, H. Koseki, M. Kanno, M. Taniguchi, Requirement for $V_{\alpha} 14$ NKT cells in IL-12-mediated rejection of tumors, Science 278 (1997) 1623-1626.

[16] S. Hong, M.T. Wilson, I. Serizawa, L. Wu, N. Singh, O.V. Naidenko, T. Miura, T. Haba, D.C. Scherer, J. Wei, M. Kronenberg, Y. Koezuka, L. Van Kaer, The natural killer T-cell ligand $\alpha$-galactosylceramide prevents autoimmune diabetes in non-obese diabetic mice, Nat. Med. 7 (2001) 1052-1056.

[17] N.Y. Crowe, J.M. Coquet, S.P. Berzins, K. Kyparissoudis, R. Keating, D.G. Pellicci, Y. Hayakawa, D.I. Godfrey, M.J. Smyth, Differential antitumor immunity mediated by NKT cell subsets in vivo, J. Exp. Med. 202 (2005) 1279-1288.

[18] S.M. Behar, S.A. Porcelli, CD1-restricted T cells in host defense to infectious diseases, Curr. Top. Microbiol. Immunol. 314 (2007) 215-250. 
[19] T. Kenna, L. Golden-Mason, S.A. Porcelli, Y. Koezuka, J.E. Hegarty, C. O'Farrelly, D.G. Doherty, NKT cells from normal and tumor-bearing human livers are phenotypically and functionally distinct from murine NKT cells, J. Immunol. 171 (2003) 1775-1779.

[20] J.W. Molling, W. Kölgen, H.J. van der Vliet, M.F. Boomsma, H. Kruizenga, C.H. Smorenburg, B.G. Molenkamp, J.A. Langendijk, C.R. Leemans, B.M. von Blomberg, R.J. Scheper, A.J. van den Eertwegh, Peripheral blood IFN- $\gamma$-secreting $V_{\alpha} 24^{+} V_{\beta} 11^{+}$NKT cell numbers are decreased in cancer patients independent of tumor type or tumor load, Int. J. Cancer 116 (2005) 87-93.

[21] D.H. Chang, K. Osman, J. Connolly, A. Kukreja, J. Krasovsky, M. Pack, A. Hutchinson, M. Geller, N. Liu, R. Annable, J. Shay, K. Kirchhoff, N. Nishi, Y. Ando, K. Hayashi, H. Hassoun, R.M. Steinman, M.V. Dhodapkar, Sustained expansion of NKT cells and antigen-specific T cells after injection of $\alpha$-galactosylceramide loaded mature dendritic cells in cancer patients, J. Exp. Med. 201 (2005) 1503-1517.

[22] S. Motohashi, A. Ishikawa, E. Ishikawa, M. Otsuji, T. lizasa, H. Hanaoka, N. Shimizu, S. Horiguchi, Y. Okamoto, S. Fujii, M. Taniguchi, T. Fujisawa, T. Nakayama, A phase I study of in vitro expanded natural killer $T$ cells in patients with advanced and recurrent non-small cell lung cancer, Clin. Cancer Res. 12 (2006) 6079-6086.

[23] M. Terabe, J. Swann, E. Ambrosino, P. Sinha, S. Takaku, Y. Hayakawa, D.I. Godfrey, S. Ostrand-Rosenberg, M.J. Smyth, J.A. Berzofsky, A nonclassical non-V $\alpha 14 \mathrm{~J} \alpha 18$ CD1d-restricted (type II) NKT cell is sufficient for down-regulation of tumor immunosurveillance, J. Exp. Med. 202 (2005) 1627-1633.

[24] J.A. Berzofsky, M. Terabe, NKT cells in tumor immunity: opposing subsets define a new immunoregulatory axis, J. Immunol. 180 (2008) 3627-3635.

[25] G. Giaccone, C.J. Punt, Y. Ando, R. Ruijter, N. Nishi, M. Peters, B.M. von Blomberg, R.J. Scheper, H.J. van der Vliet, A.J. van den Eertwegh, M. Roelvink, J. Beijnen, $H$. Zwierzina, H.M. Pinedo, A phase I study of the natural killer T-cell ligand $\alpha$-galactosylceramide (KRN7000) in patients with solid tumors, Clin. Cancer Res. 8 (2002) 3702-3709.

[26] V. Costantino, M. D'Esposito, E. Fattorusso, A. Mangoni, N. Basilico, S. Parapini, D. Taramelli, Damicoside from Axinella damicornis: the influence of a glycosylated galactose $4-\mathrm{OH}$ group on the immunostimulatory activity of $\alpha$-galactoglycosphingolipids, J. Med. Chem. 48 (2005) 7411-7417.

[27] G.W. Xing, D. Wu, M.A. Poles, A. Horowitz, M. Tsuji, D.D. Ho, C.H. Wong, Synthesis and human NKT cell stimulating properties of 3-0-sulfo- $\alpha / \beta$-galactosylceramides, Bioorg. Med. Chem. 13 (2005) 2907-2916.

[28] K. Miyamoto, S. Miyake, T. Yamamura, A synthetic glycolipid prevents autoimmune encephalomyelitis by inducing $\mathrm{TH} 2$ bias of natural killer T cells, Nature 413 (2001) 531-534.

[29] S. Oki, A. Chiba, T. Yamamura, S. Miyake, The clinical implication and molecular mechanism of preferential IL-4 production by modified glycolipid-stimulated NKT cells, J. Clin. Invest. 113 (2004) 1631-1640.

[30] R.D. Goff, Y. Gao, J. Mattner, D. Zhou, N. Yin, C. Cantu III, L. Teyton, A. Bendelac, P.B. Savage, Effects of lipid chain lengths in $\alpha$-galactosylceramides on cytokine release by natural killer $T$ cells, J. Am. Chem. Soc. 126 (2004) 13602-13603.

[31] K.O. Yu, J.S. Im, A. Molano, Y. Dutronc, P.A. Illarionov, C. Forestier, N. Fujiwara, I. Arias, S. Miyake, T. Yamamura, Y.T. Chang, G.S. Besra, S.A. Porcelli, Modulation of CD1d-restricted NKT cell responses by using $\mathrm{N}$-acyl variants of $\alpha$-galactosylceramides, Proc. Natl Acad. Sci. U.S.A. 102 (2005) 3383-3388.

[32] M. Fujio, D. Wu, R. Garcia-Navarro, D.D. Ho, M. Tsuji, C.H. Wong, Structure-based discovery of glycolipids for CD1dmediated NKT cell activation: tuning the adjuvant versus immunosuppression activity, J. Am. Chem. Soc. 128 (2006) 9022-9023.
[33] Y.J. Chang, J.R. Huang, Y.C. Tsai, J.T. Hung, D. Wu, M. Fujio, C.H. Wong, A.L. Yu, Potent immune-modulating and anticancer effects of NKT cell stimulatory glycolipids, Proc. Natl Acad. Sci. U.S.A. 104 (2007) 10299-10304.

[34] J. Schmieg, G. Yang, R.W. Franck, M. Tsuji, Superior protection against malaria and melanoma metastases by a C-glycoside analogue of the natural killer $\mathrm{T}$ cell ligand $\alpha$-galactosylceramide, J. Exp. Med. 198 (2003) 1631-1641.

[35] J.D. Silk, M. Salio, B.G. Reddy, D. Shepherd, U. Gileadi, J. Brown, S.H. Masri, P. Polzella, G. Ritter, G.S. Besra, E.Y. Jones, R.R. Schmidt, V. Cerundolo, Cutting edge: nonglycosidic CD1d lipid ligands activate human and murine invariant NKT cells, J. Immunol. 180 (2008) 6452-6456.

[36] R.T. Dere, X. Zhu, The first synthesis of a thioglycoside analogue of the immunostimulant KRN7000, Org. Lett. 10 (2008) 4641-4644.

[37] A.V. Rachitskaya, A.M. Hansen, R. Horai, Z. Li, R. Villasmil, D. Luger, R.B. Nussenblatt, R.R. Caspi, Cutting edge: NKT cells constitutively express IL-23 receptor and ROR $\gamma \mathrm{t}$ and rapidly produce IL-17 upon receptor ligation in an IL-6-independent fashion, J. Immunol. 180 (2008) 5167-5171.

[38] X. Jiang, S. Kojo, M. Harada, N. Ohkohchi, M. Taniguchi, K.I. Seino, Mechanism of NKT cell-mediated transplant tolerance, Am. J. Transplant. 7 (2007) 1482-1490.

[39] A. Karadimitris, S. Gadola, M. Altamirano, D. Brown, A. Woolfson, P. Klenerman, J.L. Chen, Y. Koezuka, I.A. Roberts, D.A. Price, G. Dusheiko, C. Milstein, A. Fersht, L. Luzzatto, V. Cerundolo, Human CD1d-glycolipid tetramers generated by in vitro oxidative refolding chromatography, Proc. Natl Acad. Sci. U.S.A. 98 (2001) 3294-3298.

[40] A. Chiba, S. Kaieda, S. Oki, T. Yamamura, S. Miyake, The involvement of $V_{\alpha} 14$ natural killer T cells in the pathogenesis of arthritis in murine models, Arthritis Rheum. 52 (2005) 1941-1948.

[41] M. Mizuno, M. Masumura, C. Tomi, A. Chiba, S. Oki, T. Yamamura, S. Miyake, Synthetic glycolipid $\mathrm{OCH}$ prevents insulitis and diabetes in NOD mice, J. Autoimmun. 23 (2004) 293-300.

[42] Y. Ueno, S. Tanaka, M. Sumii, S. Miyake, S. Tazuma, M. Taniguchi, T. Yamamura, K. Chayama, Single dose of $\mathrm{OCH}$ improves mucosal $\mathrm{T}$ helper type $1 / \mathrm{T}$ helper type 2 cytokine balance and prevents experimental colitis in the presence of V $\alpha 14$ natural killer $T$ cells in mice, Inflamm. Bowel Dis. 11 (2005) 35-41.

[43] C. Forestier, T. Takaki, A. Molano, J.S. Im, I. Baine, E.S. Jerud, P. Illarionov, R. Ndonye, A.R. Howell, P. Santamaria, G.S. Besra, T.P. Dilorenzo, S.A. Porcelli, Improved outcomes in NOD mice treated with a novel Th2 cytokine-biasing NKT cell activator, J. Immunol. 178 (2007) 1415-1425.

[44] X. Li, M. Fujio, M. Imamura, D. Wu, S. Vasan, C.H. Wong, D.D. Ho, M. Tsuji, Design of a potent CD1d-binding NKT cell ligand as a vaccine adjuvant, Proc. Natl Acad. Sci. U.S.A. 107 (2010) 13010-13015.

[45] Z.J. Witczak, Thio sugars: biological relevance as potential new therapeutics, Curr. Med. Chem. 6 (1999) 165-178.

[46] X. Zhu, R.R. Schmidt, New principles for glycoside-bond formation, Angew. Chem. Int. Ed Engl. 48 (2009) 1900-1934.

[47] M.B. Lutz, G. Schuler, Immature, semi-mature and fully mature dendritic cells: which signals induce tolerance or immunity? Trends Immunol. 23 (2002) 445-449.

[48] M.L. Blauvelt, M. Khalili, W. Jaung, J. Paulsen, A.C. Anderson, S.B. Wilson, A.R. Howell, $\alpha$-S-GalCer: synthesis and evaluation for iNKT cell stimulation, Bioorg. Med. Chem. Lett. 18 (2008) 6374-6376.

[49] J.R. Rich, A. Szpacenko, M.M. Palcic, D.R. Bundle, Glycosyltransferase-catalyzed synthesis of thiooligosaccharides, Angew. Chem. Int. Ed Engl. 43 (2004) 613-615.

[50] J.C. Wilson, M.J. Kiefel, D.I. Angus, M. von Itzstein, Investigation of the stability of thiosialosides toward hydrolysis by sialidases using NMR spectroscopy, Org. Lett. 1 (1999) 443-446. 
[51] M.J. Kiefel, R.T. Thomson, M. Radocanovi, M. von Itzstein, Synthesis of carbohydrates with an anomeric thiol moiety for elaboration into metabolically stable thioglycosides, J. Carbohydr. Chem. 18 (1999) 937-959.

[52] J.M. MacDougall, X.D. Zhang, W.E. Polgar, T.V. Khroyan, L. Toll, J.R. Cashman, Design, chemical synthesis, and biological evaluation of thiosaccharide analogues of mor- phine- and codeine-6-glucuronide, J. Med. Chem. 47 (2004) 5809-5815.

[53] Z.J. Witczak, J.M. Culhane, Thiosugars: new perspectives regarding availability and potential biochemical and medicinal applications, Appl. Microbiol. Biotechnol. 69 (2005) 237-244.

[54] H. Driguez, Thiooligosaccharides as tools for structural biology, Chembiochem 2 (2001) 311-318. 